\title{
Faktor-Faktor Yang Berhubungan Dengan Pelaksanaan K4 Di Wilayah Kerja Puskesmas Lubuk Jambi Kabupaten Kuantan Singingi
}

\author{
Erlinawati \\ Dosen DIII Kebidanan Universitas Pahlawan Tuanku Tambusai \\ email: erlinawati.ttpku@yahoo.com
}

\begin{abstract}
ABSTRAK
Menurut Survei Demografi Kesehatan Indonesia (SDKI) 2012, Angka Kematian Ibu (AKI) di Indonesia adalah 359/100.000 kelahiran hidup, Angka Kematian bayi (AKB) sebesar 32/1000 kelahiran hidup. Salah satu penyebabnya adalah belum optimalnya cakupan kunjungan antenatal Care (K4). Kurang optimalnya cakupan kunjungan K4 mengakibatkan resiko dan komplikasi kehamilan tidak terdeteksi secara dini. Di wilayah kerja Puskesmas Lubuk Jambi Kecamatan Kuantan Mudik kunjungan Antenatal K4 tahun 2014 yaitu 77,5\%, belum mencapai target kabupaten sebesar 98\%. Penelitian ini bertujuan untuk mengetahui faktor-faktor yang berhubungan dengan pelaksanaan K4 di wilayah kerja Puskesmas Lubuk Jambi Kabupaten Kuantan Singingi Tahun 2015.Penelitian ini bersifat analitik dengan desain cross sectional, menggunakan data primer,dilaksanakan di wilayah kerja Puskesmas lubuk Jambi Kabupaten Kuantan Singingiyang dilakukan pada tanggal 22 sampai 30 september 2015, dengan populasi adalah ibu hamil trimester III yaitu sebanyak 64 orang, diambil secara total sampling berdasarkan kriteria inklusi dan eksklusi dengan analisis bivariat menggunakan uji Chi Square. Hasil penelitian menunjukkan ada hubungan antara pengetahuan, motivasi dan paritas ibu terhadap pelaksanaan kunjungan $\mathrm{K} 4$, sedangkan sikap ibu tidak berhubungan dengan pelaksanaan kunjungan K4. Diharapkan kepada petugas kesehatan agar dapat memberikan motivasi yang positif kepada ibu hamil dalam melakukan kunjungan $\mathrm{K} 4$ dan memberikan informasi tentang manfaat pelaksanaan K4.
\end{abstract}

Kata Kunci : Pengetahuan, Sikap, Motivasi, Paritas, Pelaksanaan K4

Kepustakaan : 2005-2014

\section{PENDAHULUAN}

Pelayanan Antenatal Care (ANC) merupakan komponen pelayanan kesehatan oleh tenaga kesehatan profesional (dokter spesialis kandungan, dokter umum, bidan, dan perawat) kepada ibu hamil selama kehamilannya sesuai pelayanan ANC dengan titik berat pada kegiatan promotif dan preventif yang bertujuan untuk memberikan asuhan yang efektif dan menyeluruh (holistic) bagi ibu, bayi dan keluarganya melalui tindakan skrining, pencegahan dan 
penanganan yang tepat, yang mana hasil pelayanan ANC dapat dilihat dari cakupan kunjungan K4. Kunjungan K4 adalah kunjungan ibu hamil ketenaga kesehatan yang ke empat atau lebih untuk mendapatkan pelayanan Antenatal sesuai standar yang ditetapkan, yaitu "14T"'(Depkes RI, 2010). Frekuensi ANC selama kehamilan minimal 4 kali untuk mendeteksi dini terjadinya risiko terhadap kehamilan dan persalinan untuk menurunkan angka kematian ibu dan angka kematian bayi (Ratminto, 2005).

Diantara Negara ASEAN, Indonesia merupakan negara yang sedang menghadapi masalah berkaitan dengan tingginya angka mortalitas dan morbiditas. Menurut data Survei Demografi Kesehatan Indonesia (SDKI) tahun 2012, AngkaKematian Ibu (AKI) sebesar 359 per 100.000kelahiran hidup, dan Angka Kematian Bayi (AKB) 32 per 1000 kelahiran hidup.

Dinas Kesehatan Provinsi Riau pada tahun 2014 mencatat AKI sebanyak 158 kasus, apabila dibandingkan dengan tahun 2013 terjadi peningkatan, dimana jumlah kematian ibu pada tahun 2013 berjumlah 135 kasus (Dinkes Riau, 2015). AKI di Kabupaten Kuantan Singingi pada tahun 2014 sebanyak 8 kasus, dengan penyebab yang bervariasi yaitu perdarahan 2 kasus, pre ekslamsia dan ekslamsia 2 kasus, infeksi serta partus lama 3 kasus, dan lain-lain 3 kasus (Dinkes Kuansing, 2014).

Sebagai upaya antisipasi ibu hamil dianjurkan melakukan pemeriksaan ANC dengan teratur dan sesuai jadwal sehingga tujuan dari ANC dapat tercapai, salah satunya dengan mengetahui kehamilan yang berisiko tinggi sehingga dapat mencegah kematian pada ibu dan janin (Kusmiyanti, 2009). Pengawasan antenatal terbukti mempunyai kedudukan yang sangat penting dalam upaya meningkatkan kesehatan mental dan fisik ibu selama kehamilan, untuk menghadapi persalinan. Pengawasan antenatal dapat meturunkan AKI maupun AKB, sebagai gambaran kemampuan setiap bangsa untuk memberikan pelayanan dan pengayoman medis terhadap masyarakat (Kusmiyati, 2010).

Setiap ibu hamil seharusnya mendapat perawatan kehamilannya secara baik, dengan cara memeriksakan kehamilannya, tetapi pada kenyataannya masih banyak ibu hamil yang belum mengetahui secara dalam tentang pemeriksaan kehamilan yang tepat sesuai standar. Hal tersebut dapat disebabkan karena kurangnya pengetahuan ibu hamil dalam masa perawatan kehamilannya, sehingga bisa berdampak terjadinya komplikasi selama kehamilan dan persalinan yang menyebabkan bertambahnya AKI dan AKB (Stoppard, 2011).

Tingginya AKI antara lain disebabkan rendahnya tingkat pengetahuan ibu hamil dan sikap ibu hamil dalam pemeriksaan antenatal yang tidak teratur.Banyak faktor yang menyebabkan ibu hamil tidak melakukan kunjungan K4 antara lain faktor pengetahuan, sikap, motivasi dan paritas.

Sikap ibu hamil dalam kepatuhan pelaksanaan antenatal dapat ditunjukkan melalui frekuensi kunjungan, ternyata ini menjadi masalah karena tidak semua ibu 
hamil memeriksakan kehamilannya secara rutin terutama ibu hamil normal, sehingga kelainan yang timbul dalam kehamilan tidak dapat terdeteksi sedini mungkin (Prawirohardjo, 2008).

Pengawasan perinatal juga dipengaruhi oleh perilaku seseorang yang pada dasarnya terbentuk dari dua faktor yaitu faktor internal meliputi tingkat pengetahuan (kecerdasan), tingkat emosional, sikap,dan motivasi. Sementara faktor eksternal meliputi lingkungan dan pelayanan kesehatan. Jadi dapat dikatakan bahwa perilaku ibu hamil dalam merawat kehamilannya juga dipengaruhi oleh pengetahuan dan sikap ibu hamil tersebut terhadap kehamilannya (Notoadmodjo, 2010).

Selain faktor intrinsik ibu (pengetahuan, umur, dan sikap), faktor ekstrinsik (paritas, dan motivasi ) juga memengaruhi seorang ibu untuk memeriksakan kehamilannya secara teratur ke petugas pelayanan antenatal.

Berdasarkan hasil penelitian yang dilakukan oleh Komariyah (2008) tentang hubungan pengetahuan, sikap dan perilaku ibu hamil di Puskesmas Sukorame Mojoroto Kediri didapatkan hasil terdapat hubungan antara pengetahuan dan perilaku ibu hamil tentang ANC dengan pelaksanaan K4. Semakin baik tingkat pengetahuan ibu hamil tentang ANC, maka semakin tinggi pula angka cakupan kunjungan K4 di suatu wilayah. Sebaliknya semakin rendah tingkat pengetahuan seorang ibu hamil tentang ANC, maka angka cakupan kunjungan K4 disuatu wilayah juga akan rendah.
Berdasarkan hasil pemantauan wilayah setempat Kesehatan Ibu dan Anak (PWS-KIA) pada tahun 2014 di Kabupaten KuantanSingingi, cakupan ibu hamil untuk K1 100,5 \% dan K492,4\%. Bila ditinjau dari 21 Puskesmas yang ada di Kabupaten KuantanSingingi tahun 2014, Puskesmas LubukJambi adalah salah satu Puskesmas yang cakupan K4nya masih rendah atau belum mencapai target, yaitu hanya $77,5 \%$ dari sasaran ibu hamil sebanyak 431 orang, sedangkan target yang ditetapkan Dinas Kesehatan Kabupaten Kuantan Singingi untuk tahun 2014 adalah K1 98\% dan K4 $95 \%$.

Berdasarkan studi pendahuluan yang peneliti lakukan pada periode Januari sampai Februari tahun 2015 di Puskesmas Lubuk Jambi, terdapat kasus komplikasi akibat langsung dari kehamilan dan persalinan yang dirujuk ke RSUD sebanyak 10 kasus, kasusnya antara lain: Preeklampsi dan Eklamsi, partus lama, retensio plasenta, IUGR, CVD, perdarahan post partum, dan kelainan letak.

Dari penelusuran yang peneliti lakukan ke Bidan Desa yang merujuk kasus tersebut ternyata $80 \%$ dari 10 kasus yang dirujuk, terjadi pada ibu hamil yang tidak melakukan K4. Hal ini juga dipertegas dengan hasil survei tentang pengetahuan mengenai K4 yang peneliti lakukan terhadap 10 orang ibu yang pernah dirujuk, dengan mengajukan beberapa pertanyaan diperoleh data bahwa mayoritas ibu hamil berpengetahuan kurang yaitu sebanyak 7 orang, dan 3 orang berpengetahuan baik, sedangkan hasil survei tentang sikap ibu hamil mengenai $\mathrm{K} 4$, mayoritas bersikap 
negatif terhadap kunjungan K4 yaitu sebanyak 8 orang. Mereka beranggapan bahwa kunjungan K4 dilakukan apabila ada keluhan saja seperti keluhan ingin bersalin.

Survey tentang motivasi dan paritas ibu hamil, terhadap 8 orang ibu hamil yang tidak memeriksakan kehamilannya, mengatakan bahwa kehamilan dan persalinan adalah hal biasa yang akan dihadapi oleh setiap wanita, sehingga tidak perlu dilakukan pemeriksaan berulang, terutama pada ibu yang sudah memiliki lebih dari 3 orang anak, dan ditambah lagi dengan tidak adanya dukungan suami atau orang terdekat, sehingga semakin mempengaruhi ibu hamil tersebut untuk tidak melakukan pemeriksaan ANC sesuai standar. Anggapan seperti ini terjadi karena ibu hamil tersebut belum paham tentang manfaat yang akan didapatkan setelah melakukan perawatan ANC, dan belum mengetahui resiko yang mungkin terjadi selama kehamilannya, sehingga dikhawatirkan apabila terjadi kelainan atau komplikasi tidak dapat terdeteksi sedini mungkin sehingga penanganannya juga akan terlambat.

Berdasarkan latar belakang diatas, maka peneliti tertarik untuk meneliti "Faktor-faktor yang Berhubungan dengan Pelaksanaan K4 di Wilayah Kerja Puskesmas Lubuk Jambi Kabupaten Kuantan Singingi Tahun 2015”.

Adapun tujuan dalam penelitian ini yaitu untuk mengetahui faktor-faktor yang berhubungan dengan pelaksanaan K4 di wilayah kerja Puskesmas Lubuk Jambi Kabupaten Kuantan Singingi Tahun 2015.

\section{METODOLOGI PENELITIAN}

Penelitian ini bersifat analitik dengan desain penelitian cross sectional. Dilakukan untuk mengetahui Faktor-faktor yang Berhubungan dengan Pelaksanaan K4 di Wilayah Kerja Puskesmas Lubuk Jambi Kabupaten Kuantan Singingi Tahun 2015. Populasi dan sampel dalam penelitian ini adalah seluruh ibu hamil ibu hamil trimester III yang usia kehamilannya $\geq 36$ minggu yang berada di wilayah kerja Puskesmas Lubuk Jambi Kabupaten Kuantan Singingi Tahun 2015yaitusebanyak 64 orang. Teknik pengambilan sampel adalah Total sampling yaitu sampel diambil secara keseluruhan. Pengumpulan data dilaksanakan dengan menggunakan data primer yaitu data yang diperoleh langsung suatu penelitia nmengenai masalah dengan menyediakan daftar pertanyaan yang sudah tersusun baik kepada objek yang meliputi editing, coding, scoring dan tabulating. Analisa data dilakukan dengan analisa univariat dan bivariat.

\section{HASIL PENELITIAN \\ Analisis Univariat}

Analisis univariat yaitu hanya untuk memperoleh gambaran dari masing-masing variabel yang diteliti, yang akan diuraikan dengan diagram-diagram dibawah ini :

$\begin{array}{llr}\text { Tabel 1 : } & \text { Distribusi } & \text { Frekuensi } \\ \text { Responden } & \text { Berdasarkan } \\ & \text { Pengetahuan, } & \text { Sikap, } \\ & \text { Motivasi, Paritas dan } \\ \text { Pelaksanaan } \quad \text { K4 } & \text { di } \\ \text { Wilayah } & \text { Kerja } \\ \text { Puskesmas Lubuk Jambi }\end{array}$


Kabupaten Kuantan

Singingi Tahun 2015

\begin{tabular}{|c|c|c|c|}
\hline \multirow{2}{*}{ No } & \multirow{2}{*}{ Karakteristik } & \multicolumn{2}{|l|}{ Jumlah } \\
\hline & & $\mathbf{n}$ & $\%$ \\
\hline \multirow[t]{5}{*}{1} & Pengetahuan & & \\
\hline & 1. Baik & 24 & 37,5 \\
\hline & 2. Cukup & 23 & 35,9 \\
\hline & 3. Kurang & 17 & 26,5 \\
\hline & Total & 64 & 100 \\
\hline \multirow[t]{4}{*}{2} & Sikap & & \\
\hline & 1.Negatif & 30 & 46,9 \\
\hline & 2.Positif & 34 & 53,1 \\
\hline & Total & 64 & 100 \\
\hline \multirow[t]{4}{*}{3} & Motivasi & & \\
\hline & 1. Negatif & 23 & 35,9 \\
\hline & 2. Positif & 41 & 64,1 \\
\hline & Total & 64 & 100 \\
\hline \multirow[t]{4}{*}{4} & Paritas & & \\
\hline & 1. Berisiko & 42 & 65,6 \\
\hline & 2. Tidak Berisiko & 22 & 34,4 \\
\hline & Total & 64 & 100 \\
\hline \multirow[t]{4}{*}{5} & Pelaksanaan K4 & & \\
\hline & 1. Tidak & 31 & 48,4 \\
\hline & 2.Ya & 33 & 51,6 \\
\hline & Total & 64 & 100 \\
\hline \multicolumn{2}{|c|}{ et:Hasil penyebaran kuisioner } & \multicolumn{2}{|l|}{ Analisis Bivariat } \\
\hline \multicolumn{2}{|c|}{$\begin{array}{l}\text { Dari Tabel } 1 \text { diatas, dapat } \\
\text { etahui bahwa dari } 64 \text { responden, } \\
\text { agian besar responden } \\
\text { pengetahuan baik dan cukup yaitu } \\
\text { responden }(37,5 \%), \text { sebagian }\end{array}$} & $\begin{array}{l}\text { Analisis bivar } \\
\text { untuk melihat hub } \\
\text { variabel independen } \\
\text { variabel dependen. }\end{array}$ & $\begin{array}{rr}\text { iat dilakukan } \\
\text { oungan suatu } \\
\text { dengan satu }\end{array}$ \\
\hline \multicolumn{2}{|c|}{ ar responden mempunyai sikap } & Tabel 2 : Hubungan & Pengetahuan \\
\hline \multicolumn{2}{|c|}{ itif yaitu 34 responden $(53,1 \%)$, } & Dengan & Pelaksanaan \\
\hline \multicolumn{2}{|c|}{ agian besar responden memiliki } & K4 Di & Wilayah \\
\hline \multicolumn{2}{|c|}{$\begin{array}{l}\text { tivasi positif yaitu } 41 \text { responden } \\
1 \% \text { ), sebagian besar responden }\end{array}$} & Kerja & Puskesmas \\
\hline \multicolumn{2}{|c|}{$\begin{array}{l}1 \% \text {, sebagian besar responden } \\
\text { gan paritas berisiko sebanyak } 42\end{array}$} & Lubuk & Jambi \\
\hline \multicolumn{2}{|c|}{$\begin{array}{l}\text { gan paritas berisiko sebanyak } 42 \\
\text { onden }(65,6 \%) \text { dan sebagian }\end{array}$} & $\begin{array}{l}\text { Kabupaten } \\
\text { Singingi T: }\end{array}$ & $\begin{array}{l}\text { n Kuantan } \\
\text { ahun } 2015\end{array}$ \\
\hline
\end{tabular}

besar responden melaksanakan K4

yaitu 33 responden $(51,6 \%)$.

\begin{tabular}{|c|c|c|c|c|c|c|c|c|}
\hline \multirow{3}{*}{ No } & \multirow{3}{*}{ Pengetahuan } & \multicolumn{4}{|c|}{ Pelaksanaan K4 } & \multirow{2}{*}{\multicolumn{2}{|c|}{ Jumlah }} & \multirow{3}{*}{$\begin{array}{c}p \\
\text { value }\end{array}$} \\
\hline & & \multicolumn{2}{|c|}{ Ya } & \multicolumn{2}{|c|}{ Tidak } & & & \\
\hline & & $\mathbf{n}$ & $\%$ & $\mathbf{n}$ & $\%$ & $\mathbf{n}$ & $\%$ & \\
\hline 1 & Baik & 22 & 91,7 & 2 & 8,3 & 24 & 100 & \multirow{2}{*}{$\mathbf{0 , 0 0 0}$} \\
\hline 2 & Cukup & 12 & 52,2 & 11 & 47,8 & 23 & 100 & \\
\hline
\end{tabular}




\begin{tabular}{rrrrrrrr}
3 & Kurang & $\mathbf{1 7}$ & $\mathbf{1 0 0}$ & 0 & 0 & 17 & 100 \\
\hline Jumlah & $\mathbf{3 1}$ & $\mathbf{4 8 , 4}$ & $\mathbf{3 3}$ & $\mathbf{5 1 , 6}$ & $\mathbf{6 4}$ & $\mathbf{1 0 0}$ \\
\hline
\end{tabular}

Ket : Hasil Penelitian dilakukan dengan uji statistik Chi Square

Dari Tabel 2 diketahui bahwa dari 24 responden yang mempunyai pengetahuan baik, terkecil tidak melaksanakan kunjungan $\mathrm{K} 4$ yaitu 2 orang $(8,3 \%)$, selebihnya 22 orang $(91,7 \%)$ melaksanakan kunjungan $\mathrm{K} 4$, sedangkan dari 17 responden yang mempunyai pengetahuan kurang, melakukan kunjungan K4 yaitu 17 orang (100\%). Dari hasil uji statistik diperoleh nilai $p$ value $=$ 0,000 atau $p$ value $<0,05$ yang artinya ada hubungan antara pengetahuan dengan pelaksanaan K4.

Tabel 3 : Hubungan Sikap Dengan Pelaksanaan K4 Di Wilaya Kerja Puskesmas Lubuk Jambi Kabupaten Kuantan Singingi Tahun 2015

\begin{tabular}{|c|c|c|c|c|c|c|c|c|c|c|}
\hline \multirow{3}{*}{ No } & \multirow{3}{*}{ Sikap } & \multicolumn{4}{|c|}{ Pelaksanaan K4 } & \multirow{2}{*}{\multicolumn{2}{|c|}{ Jumlah }} & \multirow{3}{*}{$\begin{array}{c}p \\
\text { value }\end{array}$} & \multirow{3}{*}{$\mathbf{R R}$} & \multirow{2}{*}{$95 \% \mathrm{CI}$} \\
\hline & & \multicolumn{2}{|c|}{ Ya } & \multicolumn{2}{|c|}{ Tidak } & & & & & \\
\hline & & $\mathbf{n}$ & $\%$ & $\mathbf{n}$ & $\%$ & $\mathbf{n}$ & $\%$ & & & \\
\hline 1 & Positif & 16 & 47,1 & 18 & 52,9 & 34 & 100 & 1,000 & $\mathbf{0 , 8 8 9}$ & $\begin{array}{c}0,333- \\
2,375\end{array}$ \\
\hline 2 & Negatif & 15 & 50 & 15 & 50 & 30 & 100 & & & \\
\hline & alah & 31 & 48,4 & 33 & 51,6 & 64 & 100 & & & \\
\hline
\end{tabular}

\section{Ket : Hasil Penelitian dilakukan dengan uji} statistik Chi Square

Dari Tabel 3 diketahui bahwa dari 34 responden yang mempunyai sikap positif, sebagian besar tidak melaksanakan kunjungan $\mathrm{K} 4$ yaitu 18 orang $(52,9 \%)$, selebihnya 16 orang $(47,1 \%)$ melaksanakan kunjungan $\mathrm{K} 4$, sedangkan dari 30 responden yang mempunyai sikap negatif, sebagian besar melaksanakan kunjungan K4 yaitu 15 orang (50\%), selebihnya 15 orang (50\%) tidak melaksanakan kunjungan K4. Dari hasil uji statistik diperoleh nilai $p$ value $=1,000$ atau $p$ value $>0,05$ yang artinya tidak ada hubungan antara sikap dengan pelaksanaan K4.

Tabel 4 : Hubungan Motivasi Dengan Pelaksanaan K4 Di Wilayah Kerja Puskesmas Lubuk Jambi Kabupaten Kuantan Singingi Tahun 2015

\begin{tabular}{|c|c|c|c|c|c|c|c|c|c|c|}
\hline \multirow{3}{*}{ No } & \multirow{3}{*}{ Motivasi } & \multicolumn{4}{|c|}{ Pelaksanaan K4 } & \multirow{2}{*}{\multicolumn{2}{|c|}{ Jumlah }} & \multirow{3}{*}{$\begin{array}{c}p \\
\text { value }\end{array}$} & \multirow{2}{*}{$\mathbf{R R}$} & \multirow{2}{*}{$\begin{array}{c}95 \% \\
\text { CI } \\
\end{array}$} \\
\hline & & \multicolumn{2}{|c|}{ Ya } & \multicolumn{2}{|c|}{ Tidak } & & & & & \\
\hline & & $\mathbf{n}$ & $\%$ & $\mathbf{n}$ & $\%$ & $\mathbf{n}$ & $\%$ & & & \\
\hline 1 & Positif & 25 & 61 & 16 & 39 & 41 & 100 & 0,016 & 4,427 & $\begin{array}{l}1,441- \\
13,602\end{array}$ \\
\hline 2 & Negatif & 6 & 26,1 & 17 & 37,9 & 23 & 100 & & & \\
\hline & Jumlah & 31 & 48,4 & 33 & 51,6 & 64 & 100 & & & \\
\hline
\end{tabular}


Dari Tabel 4 diketahui bahwa dari 41 orang responden yang mempunyai motivasi positif, terkecil tidak melaksanakan kunjungan K4 yaitu 16 orang (39\%), selebihnya 25 orang $(61 \%)$ melaksanakan kunjungan K4, sedangkan dari 23 orang responden yang mempunyai motivasi negatif, terkecil melaksanakan kunjungan K4 yaitu 6 orang $(26,1 \%)$, selebihnya 17 orang $(37,9)$ tidak melakukan kunjungan

K4. Dari hasil uji statistik diperoleh nilai risiko relative $(\mathrm{RR})=4,427$. 95\% $\mathrm{CI}=1,441-13,602$ dan $p$ value $=0,016$ atau $p$ value <0,05 yang artinya ada hubungan antara motivasi dengan pelaksanaan K4.

\section{Tabel 5 : Hubungan Paritas Dengan Pelaksanaan K4 Di Wilayah Kerja Puskesmas Lubuk Jambi Kabupaten Kuantan Singingi Tahun 2015}

\begin{tabular}{|c|c|c|c|c|c|c|c|c|c|c|}
\hline \multirow{3}{*}{$\begin{array}{l}\mathbf{N} \\
\mathbf{0}\end{array}$} & \multirow{3}{*}{ Paritas } & \multicolumn{4}{|c|}{ Pelaksanaan K4 } & \multirow{2}{*}{\multicolumn{2}{|c|}{ Jumlah }} & \multirow{3}{*}{$\begin{array}{c}p \\
\text { value }\end{array}$} & \multirow{3}{*}{$\mathbf{R R}$} & \multirow{3}{*}{$\begin{array}{c}95 \% \\
\text { CI }\end{array}$} \\
\hline & & \multicolumn{2}{|c|}{ Ya } & \multicolumn{2}{|c|}{ Tidak } & & & & & \\
\hline & & $\mathrm{n}$ & $\%$ & $\mathbf{n}$ & $\%$ & $\mathrm{n}$ & $\%$ & & & \\
\hline 1 & Tidak Berisiko & 17 & 77,3 & 5 & 22,7 & 22 & 100 & 0,002 & 6,800 & $\begin{array}{l}2,078- \\
22,256\end{array}$ \\
\hline 2 & Berisiko & 14 & 33,3 & 28 & 66,7 & 42 & 100 & & & \\
\hline & Jumlah & 31 & 48,4 & 33 & 51,6 & 64 & 100 & & & \\
\hline
\end{tabular}

bahwa dari 22 orang responden yang tidak berisiko, terkecil tidak melaksanakan kunjungan K4 yaitu 5 orang $(22,7 \%)$, selebihnya 17 orang $(77,3 \%)$ melaksanakan kunjungan K4. Sedangkan dari 42 orang responden yang berisiko, terkecil melaksanakan kunjungan K4 yaitu 14 orang $(33,3 \%)$, selebihnya 28 orang $(66,7 \%)$ tidak melaksanakan kunjungan K4. Dari hasil uji statistik diperoleh nilai risiko relative $(\mathrm{RR})=$ 6,800. 95\% CI $=2,078-22,256$ dan $p$ value $=0,002$ atau $p$ value $<0,05$ yang artinya ada hubungan antara paritas dengan pelaksanaan K4.

\section{PEMBAHASAN}

\section{A. Hubungan Pengetahuan Ibu} Hamil Dengan Pelaksanaan K4

Dari hasil uji statistik diperoleh nilai $p$ value $=0,000$ atau $p$ value $<0,05$ yang artinya
Dari hasil penelitian ini peneliti berasumsi bahwa ibu hamil yang memiliki pengetahuan baik tentang ANC, akan mempunyai kepatuhan dalam melakukan pemeriksaan ANC sesuai standar sampai kunjungan $\mathrm{K} 4$, karena dengan pemeriksaan ANC yang teratur masalah ataupun komplikasi dalam kehamilan dapat diketahui dengan segera dan dapat dilakukan tindakan pertolongan secepat dan setepat mungkin. Pengawasan pada masa kehamilan melalui pemeriksaan ANC akan memberi manfaat pada ibu hamil karena ibu dan janinnya dapat segera diselamatkan apabila mengalami masalah dalam kehamilannya. Pengawasan tersebut antara lain adalah pemeriksaan sesuai standar ANC 14T secara teratur terutama pada ibu dengan paritas tinggi. 
Dalam kunjungan ANC setiap ibu hamil perlu diberi pengetahuan tentang pengertian ANC, tujuan ANC, jadwal kunjungan ANC, standar pelayanan ANC dan hal-hal penting lainnya yang dilakukan pada saat kunjungan ANC, seperti mengenal tanda-tanda bahaya dalam kehamilan, persiapan persalinan serta cara perawatan diri selama kehamilan.

Menurut peneliti tujuan kunjungan $\mathrm{K} 4$ adalah menyiapkan sebaik-baiknya fisik dan mental, serta menyelamatkan ibu dan anak dalam kehamilan, persalinan, dan masa nifas sehingga ibu post partum bisa sehat dan normal tidak hanya fisik tetapi juga mental, tentunya untuk mencapai hal tersebut perlu didukung dengan tingkat pengetahuan yang baik dari seorang ibu hamil

Salah satu penyebab masih rendahnya pengetahuan ibu hamil tentang ANC adalah kurangnya informasi yang mereka dapatkan, khususnya informasi tentang pentingnya pemeriksaan ANC sesuai standar. Menurut peneliti hal ini terjadi pada 17 orang responden yang memiliki pengetahuan kurang, karena dari penelusuran yang peneliti lakukan melalui bidan desa yang bersangkutan dapat diketahui bahwa karena ibu hamil tersebut kurang melakukan kontak ketenaga kesehatan sehingga mereka kurang mendapatkan informasi-informasi tentang ANC, sedangkan informasi kesehatan berupa pendidikan/penyuluhan kesehatan kepada ibu hamil dianggap sangat penting karena merupakan suatu upaya untuk menciptakan perilaku yang sadar akan pentingnya pemeliharaan kesehatan terutama bagi ibu hamil.

\begin{tabular}{lrr}
\multicolumn{2}{c}{ Peneliti } & berkesimpulan \\
bahwa faktor & pengetahuan \\
mempengaruhi dalam pelaksanaan & kunjungan $\quad$ K4. & Tingkat \\
pengetahuan & yang & rendah
\end{tabular} merupakan salah satu hambatan dalam proses perubahan perilaku kesehatan kearah yang lebih baik. Dengan adanya pengetahuan ibu tentang manfaat dari kunjungan K4 dan jadwal minimal pemeriksaan selama hamil, sehingga dapat mengetahui apakah ada tanda bahaya dalam kehamilan, akan memberi motivasi yang kuat bagi ibu hamil untuk memeriksakan kehamilannya sesuai standar. Menurut pendapat peneliti semakin sering ibu hamil memeriksakan kehamilannya, maka pengetahuan ibu tentang ANC akan semakin luas, dan semakin baik pengetahuan ibu hamil tentang ANC maka semakin teratur pula dalam melakukan kunjungan $\mathrm{K} 4$.

Hasil penelitian ini sesuai dengan penelitian yang dilakukan oleh Komariyah (2008), tentang hubungan pengetahun, sikap dan perilaku ibu hamil dengan pemeriksaan ANC di Wilayah Kerja Puskesmas Sukorame Mojoroto Kediri, didapatkan hasil terdapat hubungan antara pengetahuan ibu hamil dengan pemeriksaan ANC dengan nilai $p$ value $=0,000$. Artinya semakin baik pengetahuan ibu hamil maka akan melakukan pemeriksaan 
ANC, sebaliknya semakin kurang pengetahuan ibu hamil tentang pemeriksaan ANC maka ibu hamil tidak akan memeriksakan kehamilannya.

Penelitian lain yang dilakukan oleh Vitriyani (2012), tentang faktor-faktor yang berhubungan dengan pemeriksaan K4ibu hamil di Kecamatan Polokarto Kabupaten Sukoharjo, didapatkan hasil terdapat hubungan antara pengetahuan ibu hamil dengan pemeriksaanK4 dengan nilai $p$ value $=0,000$. Artinya semakin baik pengetahuan ibu hamil tentang ANC maka ibu hamil akan melakukan pemeriksaan K4.

Dari hasil penelitian bahwa ibu hamil yang tidak melakukan kunjungan $\mathrm{K} 4$ disebabkan karena kurangnya pengetahuan tentang ANC, penelitian ini sesuai dengan teori Notoatmodjo, bahwa pengetahuan merupakan domain yang sangat penting untuk terbentuknya tindakan pada seseorang. Pengetahuan diperlukan sebagai dorongan sikap dan perilaku setiap hari, sehingga dapat dikatakan bahwa pengetahuan merupakan stimulasi terhadap tindakan seseorang. Pengetahuan akan mempengaruhi seseorang dalam meningkatkan kesehatan secara kondusif, semakin baik pengetahuan seseorang maka semakin baik pula sikap dan sebaliknya apabila pengatahuan kurang baik maka kurang baik pula sikapnya.

Dari hasil penelitian dapat terlihat bahwa pengetahuan ibu hamil yang baik diikuti dengan tindakan melakukan kunjungan
$\mathrm{K} 4$, hal ini terbukti dengan mayoritas ibu berpengetahuan baik dan cukup sebanyak 24 orang $(37,5 \%)$ dan melakukan kunjungan K4. Disisi lain ibu yang memiliki pengetahuan kurang sebanyak 17orang (100\%) dan tidak melakukan kunjungan K4.

Teori yang mendukung hasil penelitian ini adalah dalam buku Notoatmodjo, yang dalam teorinya menyatakan bahwa, pengetahuan dapat dikatakan sebagai pengalaman yang mengarah pada kecerdasan serta akan meningkatkan minat dan perhatian, karena dari pengalaman dan penelitian ternyata sesuatu yang didasari oleh pengetahuan akan lebih baik dari pada yang tidak didasari oleh pengetahuan. Pengetahuan akan membentuk sikap ibu, semakin baik pengetahuan individu tentang masalah kesehatan akan sangat membantu dalam pencegahan terjadinya masalah kesehatan tersebut. Pengetahuan dapat membentuk keyakinan tertentu sehingga seseorang akan lebih mudah sesuai dengan keyakinan tersebut, termasuk dalam mendiagnosis kasus obstetri. Suatu tindakan yang didasari oleh pengetahuan akan lebih melekat dan tahan lama dibandingkan dengan yang tidak didasari oleh pengetahuan.

\section{B. Hubungan Sikap Ibu Hamil Dengan Pelaksaanaan K4}

Dari hasil uji statistik diperoleh nilai $p$ value $=1,000$ atau $p$ value $>0,05$ yang artinya tidak ada hubungan antara sikap dengan pelaksanaan $\mathrm{K} 4$. 
Berdasarkan hasil penelitian ini, peneliti berasumsi bahwa sikap ibu hamil yang tidak berhubungan dengan pelaksanaan K4 disebabkan karena mayoritas ibu hamil telah memiliki sikap positif, hal ini juga dibuktikan dengan sebagian besar pengetahuan ibu hamil yang baik. Semakin baik pengetahuan ibu hamil maka akan semakin positif sikap ibu hamil terhadap pelaksanaan $\mathrm{K} 4$, begitu juga sebaliknya semakin positif sikap ibu hamil maka akan melakukan kunjungan K4.

Hasil penelitian ini sesuai dengan penelitian yang dilakukan oleh Komariyah (2008), tentang hubungan pengetahun, sikap dan perilaku ibu hamil dengan pemeriksaan ANC di Wilayah Kerja Puskesmas Sukorame Mojoroto Kediri, didapatkan hasil tidak terdapat hubungan antara sikap ibu hamil dengan pemeriksaan ANC dengan nilai $p$ value $=0,798$. Artinya semakin positif sikap ibu hamil maka akan melakukan pemeriksaan ANC, sebaliknya apabila ibu hamil bersikap negatif maka tidak akan memeriksakan kehamilannya.

Sikapibu hamil yang positif tentang kunjungan ANC sehingga sebagian besar melakukan kunjungan $\mathrm{K} 4$ sesuai dengan teori Notoatmodjo (2012), yang mengatakan bahwa sikap merupakan suatu kecendrungan untuk memberikan respon terhadap suatu obyek atau sekumpulan obyek dalam bentuk perasaan-perasaan memihak (favorable) maupun tidak memihak (unfavorable) melalui proses interaksi komponenkomponen sikap yaitu kognitif (pengetahuan), afektif (perasaan), dan konatif (kecenderungan bertindak). Tori Rahayuningsih (2008), juga mengatakan hal senada bahwa secara sederhana sikap dapat didefenisikan sebagai ekspresi sederhana dari bagaimana kita suka atau tidak suka terhadap beberapa hal dan pada akhirnya menentukan perilaku seseorang.

\section{Hubungan Motivasi Ibu Hamil Dengan Pelaksanaan K4}

Dari hasil uji statistik diperoleh nilai risiko relative $(\mathrm{RR})=4,427$. 95\% CI $=1,441$ 13,602 dan $p$ value $=0,016$ atau $p$ value $<0,05$ yang artinya ada hubungan antara motivasi dengan pelaksanaan K4.

Berdasarkan hasil jawaban responden diperoleh bahwa sebagian responden mendapat motivasi yang baik dari keluarga. Bila dikaji dari karakteristik, mayoritas responden berada pda paritas tidak berisiko. Menurut peneliti, dari data diatas menunjukkan bahwa riwayat paritas ibu hamil juga mempengaruhi motivasi keluarga, primipara akan cenderung melaksanakan ANC, karena merupakan kehamilan yang pertama dan memiliki kecemasan dalam kehamilannya dikarenakan tidak mempunyai pengalaman. Dalam hal ini untuk meningkatkan motivasi ibu diperlukan peran suami atau keluarga untuk memberi dukungan bahwa pemeriksaan kehamilan sangat penting dalam menurunkan angka kesakitan ibu 
dan anak. Dengan memeriksakan kehamilan akan menjamin setiap calon ibu menjaga kesehatannya dan semua perawatan untuk calon bayinya seperti dalam pemenuhan nutrisi ibu.

Menurut peneliti peran suami saat isteri hamil dapat membantu ketenangan jiwa istri. Kasih sayang dan perhatian suami penting sehingga tampak keharmonisan dalam rumah tangga menjelang hadirnya buah cinta yang diharapkan. Isteri yang diperhatikan dan dikasihi oleh suami selama hamil akan menunjukkan lebih sedikit gejala emosi dan komplikasi persalinan, maka ibu akan terbantu dengan adanya motivasi keluarga.

Hasil penelitian ini sesuai dengan penelitian yang dilakukan oleh Purwanti (2014) tentang hubungan motivasi ibu hamil trimester III dengan kepatuhan kunjungan Antenatal Care (ANC) Di Wilayah Kerja Puskesmas Kaliwates Kabupaten Jember, diperoleh hasil terdapat hubungan antara motivasi ibu hamil trimester III dengan kepatuhan kunjungan ANC, artinya semakin ibu hamil diberi motivasi maka akan semakin melakukan kunjungan kehamilan ke tenaga kesehatan, sebaliknya apabila ibu hamil tidak mendapatkan motivasi maka cenderung untuk tidak memeriksakan kehamilannya.

Ibu hamil yang memiliki motivasi yang baik, akan mempengaruhi tingkat pemanfaatan pelayanan ANC. Dalam penelitian ini motivasi keluarga merupakan motivasi ekstrinsik, yaitu motivasi yang datangnya dari luar individu. Teori yang mendukung hasil penelitian ini adalah teori Sardiman (2007), yang mengatakanbahwamotivasi mempunyai arti dorongan, berasal dari bahasa latin Movere yang berarti mendorong atau menggerakkan. Motivasi inilah yang mendorong seseorang untuk berperilaku dan beraktifitas dalam pencapaian tujuan. Adanya hubungan antara motivasi dengan kunjungnan K4 dikarenakan adanya bentuk dorongan dari orang terdekat yang dimiliki oleh seorang ibu, yang sangat berpengaruh dalam memanfaatkan pelayanan ANC.Ibu hamil yang memiliki motivasi positif tentang ANC akan melakukan kunjungan K4 sesuai standar karena memiliki dorongan yang menggerakan ibu hamil tersebut untuk bertindak. Berdasarkan beberapa teori dalam penelitian ini menyangkut pelaksanaan $\mathrm{K} 4$, maka dapat disimpulkan bahwa motivasi ibu hamil dalam pelaksanaan $\mathrm{K} 4$ merupakan suatu dorongan yang terdapat dalam diri ibu sehingga menimbulkan, mengarahkan, dan mengorganisasikan tingkah lakunya. Hal ini terkait dengan upaya untuk memenuhi kebutuhan yang dirasakan ibu hamil yaitu untuk meningkatkan derajat kesehatannya.

D. Hubungan Paritas Ibu Hamil Dengan Pelaksanaan K4

Dari hasil uji statistik diperoleh nilai risiko relative $(\mathrm{RR})=6,800.95 \% \mathrm{CI}=2,078$ 22,256 dan $p$ value $=0,002$ atau $p$ value $<0,05$ yang artinya ada 
hubungan antara paritas dengan pelaksanaan K4.

Berdasarkan

hasil

penelitian, ibu hamil dengan

paritas tidak berisiko lebih cendrung melakukan kunjungan K4 dibandingkan ibu yang berisiko. Dari hasil wawancara yang peneliti lakukan terhadap ibu hamil dengan paritas $\geq 3$ dapat peneliti simpulkan bahwa hal tersebut disebabkan karena kehamilan pertama merupakan kehamilan yang sangat diharapkan dan ditunggu-tunggu oleh ibu dan pasangan. Pada kehamilan yang pertama, ibu tentu belum mempunyai pengalaman tentang perawatan kehamilan, sehingga ibu hamil akan melakukan kunjungan ANC secara teratur untuk mengetahui perkembangan kehamilannya dan berkonsultasi tentang masalah yang dirasakan seputar kehamilannya, sebaliknya seorang ibu yang sudah pernah hamil dan melahirkan 3 kali atau lebih akan menganggap kehamilan saat ini merupakan hal biasa saja, sehingga ibu merasa tidak perlu melakukan kunjungan ANC secara teratur.

Hasil penelitian ini sesuai dengan penelitian yang dilakukan oleh Putri (2014), tentang Hubungan Antara Status Paritas Dengan Motivasi Ibu Hamil Dalam Melakukan Pemeriksaan Kehamilan Di Wilayah Kerja Puskesmas Lebak Barang Kabupaten Pekalongan, didapatkan hasil bahwa ada hubungan secara statistik antara paritas ibu $\geq$ 3orang dengan pemeriksaan kehamilan, artinya semakin banyak jumlah anak yang dimiliki oleh ibu maka akan lebih cenderung untuk tidak memeriksakan kehamilannya.

Penelitian ini juga sesuai dengan teori Prawirohardjo (2008), yang mengatakan bahwa bagi ibu yang baru pertama kali hamil, ANC merupakan suatu hal yang baru sehingga ibu memiliki motivasi yang tinggi dalam memeriksakan kehamilannya. Sebaliknya ibu yang sudah pernah hamil dan melahirkan 3 kali atau lebih mempunyai anggapan bahwa sudah memiliki pengalaman sehingga tidak termotivasi untuk memeriksakan kehamilannya. Hal senada juga sesuai dengan teori menurut Winkjosastro (2005), bahwa ibu yang pertama kali hamil merupakan hal yang sangat baru sehingga termotivasi dalam memeriksakan kehamilannya ketenaga kesehatan. Sebaliknya ibu yang sudah pernah melahirkan lebih dari tiga orang anak mempunyai anggapan bahwa ibu sudah berpengalaman sehingga tidak termotivasi untuk memeriksakan kehamilannya.

\section{KESIMPULAN}

Dari hasil penelitian dan pembahasan yang telah diuraikan dalam bab sebelumnya, maka dapat disimpulkan bahwa :

1. Terdapat hubungan pengetahuan ibu hamil dengan pelaksanaan K4.

2. Tidak Terdapat hubungan sikap ibu hamil dengan pelaksanaan K4.

3. Terdapat hubungan motivasi ibu hamil dengan pelaksanaan K4.

4. Terdapat hubungan paritas ibu 
hamil dengan pelaksanaan K4.

\section{DAFTAR PUSTAKA}

Ayu, P, 2014. Aplikasi Metodologi Penelitian Kebidanan dan Kesehatan Reproduksi. Nuha Medika: Yogyakarta

Budiman dan Riyanto. 2013. Kapita Selekta Kuesioner. Salemba Medika. Jakarta

Depkes RI. 2010. Pedoman Pelayanan Antenatal di Tingkat Pelayanan Dasar Puskesmas: Jakarta 2013. Pedoman

Pelayanan Antenatal: Jakarta

Hasnaeni. 2011. Hubungan Pengetahuan dan Sikap Ibu Hamil Terhadap Kepatuhan Pelaksanaan Antenatal Care (ANC) di Puskesmas Antang Raya Makassar: Tesis

Hidayat, A. A. 2012. Pengantar Ilmu Keperawatan Anak 1. Salemba Medika : Jakarta

Husada, 2013 .Ilmu Pengetahuan. Bandung : Rosda Karya

Ina, K. 2014 Asuhan Kehamilan. Pustaka Pelajar: Yogyakarta

Kemenkes RI. 2013. Profil Kesehatan Indonesia tahun 2012. Jakarta

Kusmiyati, Y. 2010. Perawatan Ibu Hamil (Asuhan Ibu Hamil). Fitramaya Yogyakarta

Komariah, S. 2008. Hubungan Pengetahun, Sikap dan Perilaku Ibu Hamil tentang Antenatal Care (ANC) Dengan Pemeriksaan ANC di Wilayah Kerja Puskesmas Sukorame Mojoroto Kediri : Tesis

Manuaba dan I. B. G. Manuaba. 2007. Mamahami Kesehatan
Reproduksi Wanita. Jakarta: Penerbit Buku Kedokteran EGC.

Notoatmodjo, S. 2010. Ilmu Perilaku Kesehatan. Jakarta : Rineka Cipta

Kesehatan Masyarakat.

Rineka Cipta. Jakarta 2010, Metodologi

Penelitian Kesehatan, Jakarta :Rineka Cipta

Nursalam.2013.Konsep dan Penerapan Metodologi Penelitian Ilmu Keperawatan. Salemba Medika. JakartA

Prawirohardjo, S. 2008. Ilmu Kebidanan. Yayasan Bina Pustaka: Jakarta

Purwanti, A. 2014. Hubungan Motivasi Ibu Hamil Trimester III Dengan Kepatuhan Kunjungan Antenatal Care (ANC) Di Wilayah Kerja Puskesmas Kaliwates Kabupaten Jember. Skripsi

Putri, 2014. Hubungan Antara Status

Paritas Dengan Motivasi Ibu Hamil Dalam Melakukan Pemeriksaan Kehamilan Di Wilayah Kerja Puskesmas Lebak Barang Kabupaten Pekalongan. Skripsi

Vitriyani. 2012. Faktor-faktor yang Berhubungan Dengan Pemeriksaan Antenatal Care (ANC) K4 di Kecamatan Polokarto Kabupaten Sukoharjo: Skripsi

Winkjosastro, 2005. Ilmu Kebidanan. Yayasan Bina Pustaka Sarwono. Jakarta. 
